\title{
Eugenol isolated from Syzygium aromaticum inhibits HeLa cancer cell migration by altering epithelial-mesenchymal transition protein regulators
}

\author{
Happy Kurnia Permatasari ${ }^{1 *}$, Andika Bachtiar Effendi², Faqrizal Ria Qhabibi ${ }^{2}$, Fadhil Fawwaz ${ }^{2}$, Anita Dominique ${ }^{2}$ \\ ${ }^{1}$ Department of Biochemistry and Biomolecular, Faculty of Medicine Brawijaya University, Malang, Indonesia. \\ ${ }^{2}$ Medical Study Program, Faculty of Medicine Brawijaya University, Malang, Indonesia.
}

\begin{tabular}{l}
\hline ARTICLE INFO \\
\hline Received on: $14 / 09 / 2020$ \\
Accepted on: 22/12/2020 \\
Available online: 05/05/2021 \\
\\
\hline Key words: \\
Cervical cancer, E-cadherin, \\
epithelial-mesenchymal \\
transition, eugenol, HeLa cell, \\
vimentin.
\end{tabular}
vimentin.

\begin{abstract}
Cervical cancer is caused by persistent human papilloma virus types 16 and 18 infections. This cancer is classified as a malignancy due to its capability to invade and seed at distant sites to form metastases. Lymph nodes metastasis areis an important factor relating to cervical cancer survival. Our previous study reported eugenol from clove oil (Syzygium aromaticum) has anti-cancer effects by inducing apoptosis through $\mathrm{p} 53$ protein degradation inhibition in HeLa cancer cells. In this study, we continue to examine the anti-cancer eugenol effects as an anti-metastatic agent. A true experimental research with post-test only controlled group design was carried out on four groups of HeLa cell cultures receiving different eugenol concentrations. To identify the molecular mechanisms involved in the eugenol anti-metastatic effect, eugenol- treated HeLa cells were subjected to scratch wound healing and immunofluorescence staining assays. Both qualitative and quantitative approaches were carried out to analyze the obtained data. Quantitative methods such as one-way analysis of variance, Tukey's multiple comparison test, and Pearson's correlation were carried out. We show that eugenol effectively inhibits HeLa cell wound healing migration. Furthermore, we show the eugenol effect downregulated Snail-1 and vimentin protein expression and upregulated E-cadherin protein expression. These proteins are important regulators of epithelial-mesenchymal transition pathways.
\end{abstract}

\section{INTRODUCTION}

Cancer is a non-communicable disease as a result of abnormal cell proliferation in tissues, which are characterized as either benign or malignant. Cervical cancer is a common gynecologicaly cancer that most often causes death in women (Small et al., 2017). Cervical cancer is a malignant tumor originating from the endocervical and ectocervical epithelial junction caused by persistent infection from human papilloma virus (HPV) types 16 and 18 (Eifel, 2018). Both HPV types 16 and 18 cause $75 \%$ of invasive cervical cancer (Akbar et al., 2019).

"Corresponding Author

Happy Kurnia Permatasari, Department of Biochemistry and Biomolecular, Faculty of Medicine Brawijaya University, Malang, Indonesia.E-mail: happykp@ub.ac.id
In 2018, the World Health Organization reported cervical cancer in 32,496 woman (WHO, 2018).

HPV produces two proteins that play a vital role in cervical cancer pathogenesis:, E6 protein, and E7 protein (Yang, 2013). Both E6 protein and E7 protein can inactivate apoptotic proteins in cervical epithelial cells. The E6 protein is the main protein that causes oncogenesis by binding to the p53 tumor suppressor protein, whereas the E7 protein binds and inactivates the retinoblastoma $(\mathrm{Rb})$ protein in infected cells and activates the cell cycle program (Graham, 2017; Small et al., 2017). If cell apoptotic proteins are inactivated and degraded, then cell proliferation will be abnormal and the final result is cervical cancer.

The main reason for high cervical cancer prevalence and mortality is metastasis to other sites in the body. Cervical cell cancer metastasis involves a process called the epithelial-mesenchymal transition (EMT), especially EMT type 3 (Jiang et al., 2016; Lee and Shen, 2012). Snail-1 is a zinc-finger transcription factor that 
is regulated by the PI3K/Akt signaling pathway and increases EMT by downregulating E-cadherin and upregulating vimentin (Myong, 2012; Xu et al., 2015). EMT changes epithelial cells to mesenchymal cells, causing loss of cell adhesion and polarity (Ha et al., 2013). These changes in characteristics increase migration capacity, invasion, apoptosis resistance, and extra-cellular matrix production (Bermudez et al., 2015).

Patients with metastatic cervical cancer need more advanced treatments. In Indonesia, cervical cancer treatment includes operative treatment, chemotherapy, and radiation therapy (Permatasari et al., 2019). Recently, chemotherapy is the most common for treating metastatic cervical cancer, but using chemotherapy sometimes results in the worst side effects because the health and viability of the cells in the surrounding healthy tissues around the cancer also decrease and have a tendency to undergo necrosis. In addition, the chemotherapy treatment price is too expensive (Van Minh et al., 2017). Therefore, more effective and cheaper treatment solutions are needed. One such avenue is using natural extracts that are easily found in Indonesia, as some have proven to contain anti-cancer effects.

Indonesia is one of the biggest clove (Syzygium aromaticum) exporters in the world. Clove has an active substance called eugenol (4-allyl-2-methoxyphenol). Eugenol concentrations inside clove oil are approximately between $70 \%-$ and $96 \%$ (Bezerra et al., 2017). Eugenol contains many functional groups, such as allyl $\left(-\mathrm{CH}_{2}-\mathrm{CH}=\mathrm{CH}_{2}\right)$, phenol $(\mathrm{OH})$, and methoxy ($\mathrm{OCH}_{3}$ ) (Towaha, 2012). Recently, experiments have revealed that the active clove oil substance, eugenol, has anti-tumor properties (Jaganathan, 2012). Our previous study revealed that eugenol's anti-tumor mechanisms induce apoptosis in cancer cells by enhancing p53 protein concentrations (Permatasari et al., 2019). However, there is no research on eugenol as an anti-metastasis agent. Therefore, this study aimed to investigate eugenol's inhibitory effects on cervical cancer metastasis.

\section{MATERIALS AND METHODS}

\section{Eugenol isolation from clove oil by fractional distillation}

As much as $150 \mathrm{ml}$ of clove oil (Malang, Indonesia) was added into a round bottom flask and underwent a series of fractional distillations connected by vacuum. The pressure was controlled at $100 \mathrm{mmHg}$ and distillation was carried out. The distillate was obtained at a temperature of $80^{\circ} \mathrm{C}-82^{\circ} \mathrm{C}$ and collected in an Erlenmeyer flask. The isolated eugenol was measured by its specific gravity and analyzed by infrared spectrophotometry and high performance liquid chromatography, as previously described (Fitri and Kawira, 2006).

\section{HeLa cervical cancer cell culture}

Cervical cancer HeLa cells were purchased from the Biomedical Laboratory, Medicine Faculty, Brawijaya University (Malang, Indonesia). Cells were incubated with $5 \% \mathrm{CO}_{2}$ at $37^{\circ} \mathrm{C}$. HeLa cells were cultured in Roswell Park Memorial Institute (RPMI)-1640 media (Roswell Park Memorial Institute, New York, NY) supplemented with 10\% fetal bovine serum (FBS), and antibiotics (100 UI/ml penicillin, $100 \mu \mathrm{l} / \mathrm{ml}$ streptomycin), and maintained at a $\mathrm{pH}$ of 7.2-7.4. HeLa cells were routinely grown and harvested with trypsin-ethylenediaminetetraacetic acid solution (You et al., 2010).

\section{Cell migration using the wound healing assay}

Cells were grown until they become monolayers in 24well plates. A p10 micropipette tip was used to manually scratch a single line in each well. The dislodged cells were washed away using RPMI medium. After the scratches were formed, cells were grown in starvation medium (FBS $0.1 \%$ ) with varying doses of eugenol $(0,50,100$, and $200 \mu \mathrm{M})$ as previously described (Permatasari et al., 2019). The wound-closing process was observed every 3 hours until the scratch in the control had fully closed. Cell pictures of each condition were taken at the same time. The scratch width was calculated using the ImmunoRatio Image J application.

\section{E-cadherin, vimentin, and snail-1 expression using immunofluorescence}

HeLa cell culture was carried out in 24-well plates with a $13 \mathrm{~mm}$ round-shaped glass cover at the bottom of each well (Matsunami, Japan). The primary antibodies used were antimouse E-cadherin (Santa Cruz, CA), anti-rabbit vimentin (Cell Signaling Technology, Danvers, MA), and anti-mouse FITC Snail-1 (Santa Cruz, CA). The secondary antibodies used were: Alexa Fluor-546 goat anti-mouse IgG (Invitrogen, Carlsbad, CA), Alexa Fluor-488 goat anti-rabbit IgG (Invitrogen, Carlsbad, CA), and Alexa Fluor-488 goat anti-mouse IgG (Invitrogen, Carlsbad, CA). The nucleus was stained with 4,6-diamidino-2-phenylindole (DAPI; Sigma-Aldrich, St. Louis, MO).

\section{Data collection and data analysis}

The results are expressed as the mean $\pm \mathrm{SD}$ of three independent experiments. The data were analyzed using GraphPad Prism 8. Measurements were statistically analyzed using the oneway analysis of variance (ANOVA), Tukey's multiple comparison test, and Pearson's correlation. A $p$-value $<0.05$ was considered statistically significant.

\section{RESULTS AND DISCUSSION}

To understand if eugenol has anti-metastatic effects on cervical cancer, we investigated ifwhether eugenol affects cell migration. HeLa cells in scratched wells were incubated with eugenol at various concentrations $(0,50,100$, and $200 \mu \mathrm{M})$ in starvation medium (FBS 0.1\%). Scratch distances were observed under a light microscope after incubating for 72 hours. The HeLa cell morphology after eugenol exposure at varying concentrations for 72 hours is shown in Figure 1A. Figure 1B shows the scratch widths of control and eugenol-treated cells, before and after incubation. Based on Figure 1B, two populations from each treatment groups with particular eugenol concentrations $(0,50,100$, and $200 \mu \mathrm{M}$ ) formed a gap with lengths of $868.8,890.2,921.1$, and $887.5 \mu \mathrm{m}$, respectively. Distance measurement was carried out after 72 hours of incubation, resulting in distance adjustment between the opposite populations in the same chamber. The control group showed a $405.1 \mu \mathrm{m}$ space after the incubation. On the other hand, groups immersed with eugenol showed a wider gap of the two cell populations, with the distance increment directly proportional to the administered eugenol concentrations: $512.1 \mu \mathrm{m}, 619.7 \mu \mathrm{m}$, and $750.4 \mu \mathrm{m}$ for $0 \mu \mathrm{M}, 50 \mu \mathrm{M}, 100 \mu \mathrm{M}$, and $200 \mu \mathrm{M}$ of eugenol, respectively. Cell migration percentage can be examined from the data above by calculating the width difference between before and 


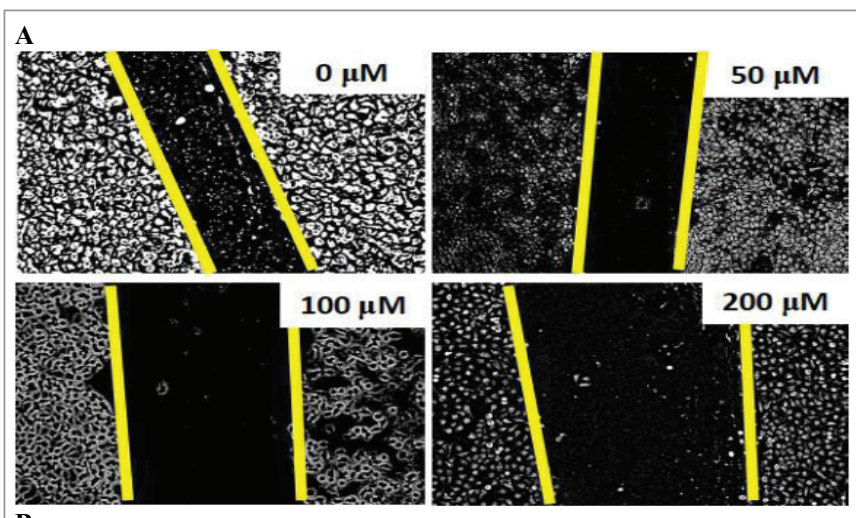

B

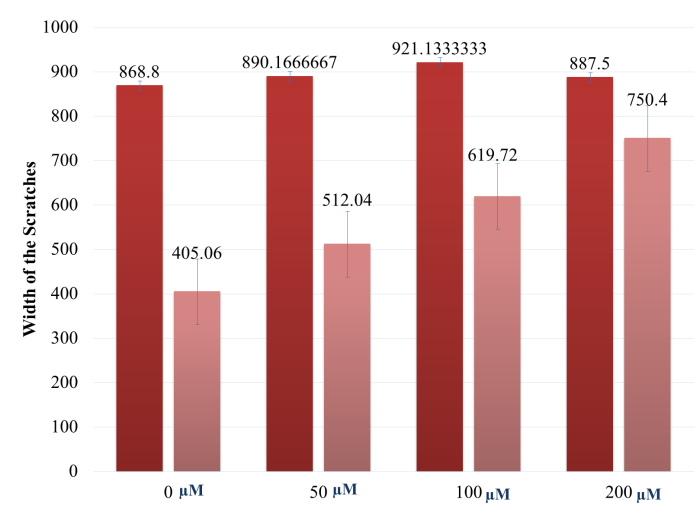

C

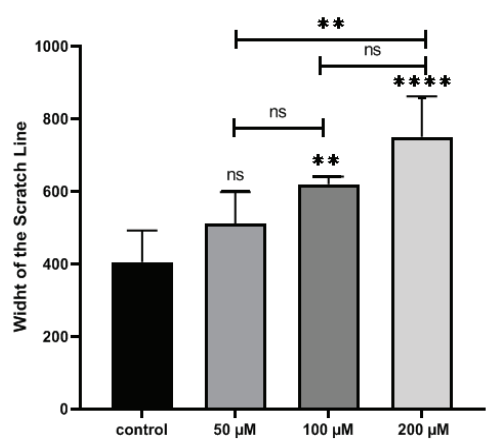

Figure 1. The eugenol effect on HeLa cells migration. Theeffect (A) HeLa cell morphology after eugenol exposure at varying concentrations for 72 hours. (B) The scratch widths before and after, for control and eugenol-treated cells. (C) Scratch width from the wound healing assay calculated using the ImmunoRatio Image $\mathbf{J}$ application. The figure shows The mean $\pm \mathrm{SD}$ is shown for three individual trials. One-way ANOVA and Tukey's multiple comparison test: $* * p$ $<0.01 ;$; and $* * * * p<0.0001$; ns $=$ : not significant.

after incubation. The percentage of cell migration on the HeLa cell culture with eugenol $0 \mu \mathrm{M}$ is $53.4 \%$. Furthermore, the HeLa cell immersed with eugenol concentrations $(50 \mu \mathrm{M}, 100 \mu \mathrm{M}$, and $200 \mu \mathrm{M}$ ) revealed a decrease of migration percentage by $42.5 \%$, $23.7 \%$, and $15.4 \%$, respectively.

The wound healing scratch width ratio was calculated using the ImageJ ImmunoRatio application using the mean from three individual experiments (Fig. 1C). Overall, we observed that HeLa cell migration was inhibited when treated with eugenol. At the highest dose $(200 \mu \mathrm{M})$, the migration rate was decreased by $3.38 \pm 1.22$-fold over the control $(p<0.0001)$. These results indicate that HeLa cell migration is significantly decreased in a dose-dependent manner, as evident by Pearson's correlation coefficient ( $r=0.9679)$.

Cervical cancer metastasis involves a process called the EMT. Decreased E-cadherin expression is associated with the EMT process. Therefore, we investigated the E-cadherin expression in HeLa cells incubated with various doses of eugenol $(0,50,100$, and $200 \mu \mathrm{M}$ ) for 24 hours. We found that there was an increase in E-cadherin levels, especially at $100 \mu \mathrm{M}$ and $200 \mu \mathrm{M}$ (Fig. 2A).

Recent studies revealed that carcinoma cells that finished their EMT process will obtain a mesenchymal phenotype and expressed mesenchymal markers, such as vimentin. We evaluated the vimentin expression in HeLa cells that were grown in the presence of eugenol using an immunofluorescence method. There was a significant decrease in vimentin expression, especially at $100 \mu \mathrm{M}$ and $200 \mu \mathrm{M}$ (Fig. 2B).

Snail-1 is a zinc-finger family transcription factor that plays an important role in the EMT process and cervical cancer cell invasion. The Snail-1 protein represses the gene that encodes for E-cadherin and stimulates the gene that encodes for vimentin. To determine the eugenol effect on Snail-1-mediated EMT, we examined Snail-1 expression in HeLa cells incubated with varying concentrations of eugenol $(0,50,100$, and $200 \mu \mathrm{M})$. The results showed a decrease in Snail-1 protein expression in a dose-dependent manner (Fig. 2C). At $200 \mu \mathrm{M}$, Snail-1 protein was completely absent.

In this research, we investigated if eugenol, an extract from clove oil ( $S$. aromaticum), had anti-metastatic effects on cervical cancer. Eugenol has anti-cancer activity for some cancer types and it wasshowed pro-apoptotic effects in cervical cancer (Towaha, 2012). Permatasari et al. (2019), demonstrated that eugenol induces apoptosis in HeLa cells. Eugenol's cytotoxic effect in HeLa cells was in the 50-200 $\mu \mathrm{M}$ range. This apoptotic occurrence is mediated by Caspase- 3 and p53 protein expression (Permatasari et al., 2019).

Baharara et al. (2015) found that eugenol can suppress breast cancer cell migration mainly through decreased MMP-9 and Paxilin gene expression.,. Unfortunately, there is still no research on eugenol in inhibiting cervical cancer migration. The results of this study reveal the anti-carcinogenic effects of eugenol, especially in HeLa cells. We show one of the anticarcinogenic eugenol effects on cervical cancer was inhibiting cell migration. The migration inhibition iswas achieved as eugenol concentrations increased, as shown by the Pearson's correlation value, $(r=0.9679)$. HeLa cells treated with $200 \mu \mathrm{M}$ eugenol exhibited the most effective cell migration inhibition. This was evident by the difference in scratch width pre- and post-scratch between the control and eugenol treated cells. The control condition closed up the wound more than the eugenol -treated cells.

Cervical cancer metastasis involves EMT (Jiang et al., 2016). EMT is stimulated by epithelial cell gene expression. Some of these genes can be traced by measuring the amount of protein product present in the cell. The result in EMT gene expression changes the overall characteristic of epithelial cells to develop mesenchymal cell characteristics. To that end, cell polarity and epithelial cell attachment to the basal membrane is lost, and metastasis occurs allowing the cell to detach and enter into the blood circulation (Kalluri and Weinberg, 2009). 


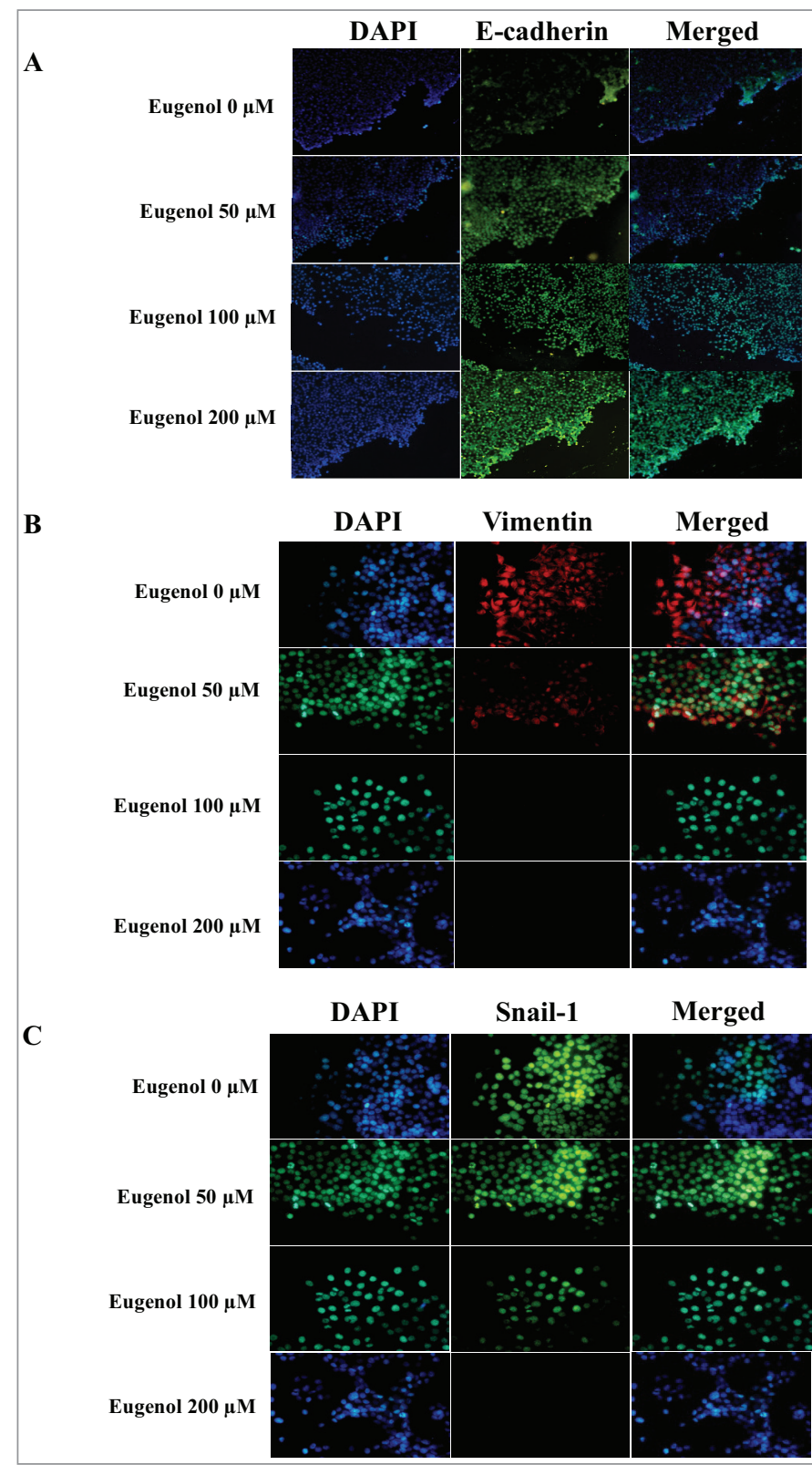

Figure 2. Eugenol effect on E-cadherin, vimentin, and Snail-1 protein expression. (A) Increased E-cadherin protein expression was observed after eugenol treatment. HeLa cells were stained for E-cadherin (green). (B) Decreased vimentin protein expression was observed after eugenol treatment. HeLa cells were stained for vimentin (red). (C) Decreased Snail-1 protein expression after eugenol treatment. HeLa cells were stained for Snail-1 (green). DAPI (blue) indicates nuclei for all panels.

Recent studies have identified several protein markers for cervical cancer progression. Myong revealed that the E-cadherin, vimentin, and Snail proteins can be used as EMT markers. The conclusion was supported by the following results. Invasive cells showed reduced E-cadherin expression and elevated vimentin expression compared to the control group. And Snail-1 protein upregulation in the invasive carcinoma group correlated with the loss of E-cadherin expression and gain of vimentin expression (Myong, 2012).

E-cadherin functions as a cell adhesion molecule and is a marker for EMT. The loss of E-cadherin expression is associated with increased EMT and frequently occurs during tumor metastasis (Petrova et al., 2016). The EMT process usually does not occur if E-cadherin expression is increased in cancer cells. This research shows E-cadherin expression increased in HeLa cells treated with eugenol, especially at $200 \mu \mathrm{M}$. This is consistent with the loss of the EMT process inhibited by administering eugenol to HeLa cells.

Carcinoma cells, after finishing the EMT process, obtained a mesenchymal phenotype and expressed mesenchymal markers such as vimentin (Lee and Shen, 2012). We show that vimentin expression decreased in HeLa cells treated with eugenol. The vimentin expression was significantly reduced at concentrations of 100 and $200 \mu \mathrm{M}$ (Figure. 2B). These results indicate eugenol is able to inhibit EMT in cervical cancer.

Snail-1, which is a powerful EMT regulator, suppresses E-cadherin expression by binding to its promoter. In addition, Snail-1 controls matrix metalloproteinase proteolytic activity associated with EMT and stromal invasion, which contributes to the upregulation of mesenchymal markers like vimentin and fibronectin (Jin, 2010; Myong, 2012; Qureshi et al., 2015). We observed Snail-1 protein expression in HeLa cells that were treated with eugenol. There was a significant decrease in Snail-1 protein expression in a dose-dependent manner. At $200 \mu \mathrm{M}$ concentration, Snail-1 protein expression was not observed. These results indicate that eugenol is able to inhibit EMT by inhibiting Snail-1 protein expression, causing a subsequent increase in E-cadherin protein expression and a decrease in vimentin protein expression. Interestingly, vimentin protein expression disappeared at $100 \mu \mathrm{M}$, whereas Snail-1 was still expressed. This observation suggests that the eugenol effect was more dominant on vimentin directly than through Snail-1 regulation.

\section{CONCLUSION}

In summary, for the first time we established that eugenol can inhibit HeLa cervical cancer cell migration. The eugenol mechanism in inhibiting migration was mediated by a decrease in vimentin and Snail-1 expression and by an increase in E-cadherin expression. However, the loss of vimentin expression preceded Snail-1 in inhibiting migration. Further research is needed to fully ascertain the eugenol inhibiting mechanism for HeLa cell migration.

\section{ACKNOWLEDGMENTS}

This experiment was supported by Faculty of Medicine Brawijaya University, Malang, Indonesia. The authors would like to thank the Biochemistry Department for providing eugenol and several antibodies. We also appreciate all Biomedical Laboratory workers and helps for analyses, discussions, and suggestions.

\section{CONFLICT OF INTEREST}

The autors declare no conflict of interest.

\section{FUNDING}

The entire experiment received a fund from Hibah Guru Besar Lembaga Penelitian dan Pengabdian Masyarakat Universitas Brawijaya.

\section{PUBLISHER'S NOTE}

This journal remains neutral with regard to jurisdictional claims in published institutional affiliation. 


\section{REFERENCES}

Akbar W, Rauf S, Riu DS, St Maisuri TC. Concordance of human papillomavirus type 16 and 18 in cervical and oral specimen of cervical cancer patients. Indones J Obstet Gynecol, 2019; 7(1):69-73.

Baharara J, Ramezani T, Mousavi M, Kouhestanian K. Eugenol suppressed metastasis of breast carcinoma cells and migration by regulation of MMP-9 \& paxilin gene expression. Sch J Agric Vet Sci, 2015; 2(2B):125-30.

Bermudez A, Bhatla N, Leung E. Cancer of the cervix uteri. Int J Gynecol Obstet, 2015; 131:S88-95.

Bezerra DP, Militão GC, De Morais MC, De Sousa DP. The dual antioxidant/prooxidant effect of eugenol and its action in cancer development and treatment. Nutrients, 2017; 9(12):1367.

Eifel, Patricia J., Ann H. Klopp, Jonathan S. Berek, and Panagiotis A. Konstantinopoulos. "Cancer of the cervix, vagina, and vulva." DeVita, Hellman, and Rosenberg's Cancer: Principles \& Practice of Oncology. Wolters Kluwer Health Pharma Solutions (Europe) Ltd, 2018. 1172-1210.

Fitri N, Kawira JA. Perbandingan variabel pada isolasi dan pemurnian eugenol dari minyak daun cengkeh. Media Penelitian dan Pengembangan Kesehatan, 2006; 16(2):156449.

Graham SV. The human papillomavirus replication cycle, and its links to cancer progression: a comprehensive review. Clin Sci, 2017; 131(17):2201-21.

Ha GH, Park JS, Breuer EK. TACC3 promotes epithelialmesenchymal transition (EMT) through the activation of PI3K/Akt and ERK signaling pathways. Cancer Lett, 2013; 332(1):63-73.

Jaganathan SK, Supriyanto E. Antiproliferative and molecular mechanism of eugenol-induced apoptosis in cancer cells. Molecules, 2012; 17(6):6290-304.

Jiang Z, Song Q, Zeng R, Li J, Li J, Lin X, Chen X, Zhang J, Zheng Y. MicroRNA-218 inhibits EMT, migration and invasion by targeting SFMBT1 and DCUN1D1 in cervical cancer. Onco Targets Ther, 2016; 7(29):45622.

Jin H, Yu Y, Zhang T, Zhou X, Zhou J, Jia L, Wu Y, Zhou BP, Feng Y. Snail is critical for tumor growth and metastasis of ovarian carcinoma. Int J Cancer, 2010; 126(9):2102-11.

Kalluri R, Weinberg RA. Erratum: the basics of epithelialmesenchymal transition. J Clin Investig, 2009; 119(6):1420-8.

Lee MY, Shen MR. Epithelial-mesenchymal transition in cervical carcinoma. Am J Transl Res. 2012; 4(1):1.

Myong NH. Loss of E-cadherin and acquisition of vimentin in epithelial-mesenchymal transition are noble indicators of uterine cervix cancer progression. Korean J Pathol. 2012; 46(4):341.
Permatasari HK, Kusuma ID, Mayangsari E. Minyak Cengkeh (Syzygium aromaticum) menginduksi apoptosis pada sel kanker servik HeLa melalui peningkatan kadar protein p53. J Kedokt Brawijaya. 2019, 30(3):185-90.

Petrova YI, Schecterson L, Gumbiner BM. Roles for E-cadherin cell surface regulation in cancer. Mol Biol Cell, 2016; 27(21):3233-44.

Qureshi R, Arora H, Rizvi MA. EMT in cervical cancer: its role in tumour progression and response to therapy. Cancer Lett. 2015; 356(2):321-31.

Small Jr W, Bacon MA, Bajaj A, Chuang LT, Fisher BJ, Harkenrider MM, Jhingran A, Kitchener HC, Mileshkin LR, Viswanathan AN, Gaffney DK. Cervical cancer: a global health crisis. Cancer. 2017; 123(13):2404-12.

Towaha J. Manfaat eugenol cengkeh dalam berbagai industri di Indonesia. Perspektif. 2012; 11(2):79-90.

Van Minh H, My NT, Jit M. Cervical cancer treatment costs and cost-effectiveness analysis of human papillomavirus vaccination in Vietnam: a PRIME modeling study. BMC Health Serv Res, 2017; 17(1):353. World Health Organization. Sexual and reproductive health cervical cancer (online). WHO, Geneva, Switzerland. 2018. Available from: https://www.who.int/reproductivehealth/topics/cancers/en/ (Accessed 20 February 2020)

$\mathrm{Xu} \mathrm{W}$, Yang Z, Lu N. A new role for the PI3K/Akt signaling pathway in the epithelial-mesenchymal transition. Cell Adh Mig, 2015; 9(4):317-24.

Yang HJ. Aberrant DNA methylation in cervical carcinogenesis. Chin J Cancer, 2013; 32(1):42.

You BR, Moon HJ, Han YH, Park WH. Gallic acid inhibits the growth of HeLa cervical cancer cells via apoptosis and/or necrosis. Food Chem Toxicol, 2010; 48(5):1334-40.

How to cite this article:

Permatasari HK, Effendi AB, Qhabibi FR, Fawwaz F, Subali AD. Eugenol isolated from Syzygium aromaticum inhibits HeLa cancer cell migration by altering epithelialmesenchymal transition protein regulators. J Appl Pharm Sci, 2021; 11(05):049-053. 